\title{
The Mubarak Regime's Failed Youth Policies and the January Uprising
}

\author{
Youssef Wardany
}

\begin{abstract}
Throughout its 30 years in power, the regime of President Mubarak failed to meet the needs of the younger generation. During the last ten years in particular, the gap between actual reality and the political rhetoric about empowering the young and allowing them to better their lives grew steadily. The regime failed to embrace a public policy for the youth that would be binding on all state institutions. It could not come up with clear goals in education, employment and political initiation. The considerable funding that went into improving the output of the educational process and creating jobs for the youth did not change this reality. Meanwhile, the National Democratic Party (NDP) placed unrealistic hopes on the commitment and loyalty of its young members, whose failure to support the regime became clear during the January 25th uprising. The regime's focus was on activities aimed to fill the time of young people, rather than on political activities that were open to all young people, regardless of their political and intellectual affiliations.
\end{abstract}

\section{The gap between rhetoric and reality}

The Mubarak era saw a growing disconnect between reality and the regime's seemingly earnest political discourse, which was all about empowering the youth and helping them achieve their full potential. This disconnect was to have serious repercussions due to the increase in the number of young people as well as their ratio in the country's demographic make-up. The ratio of young people in the 18-29 age group, totalling 19 million in August 2010, was 24.2 per cent of the total population (CAPMAS 2011). The disconnect between reality and rhetoric was due to four factors: the declining interest of President Mubarak in the young, especially in the 2000s; the failure of the political leadership to develop a national policy on youth; the instability of the organisational structures supporting youth affairs; and the inadequacies of the legislative framework governing the youth movement in Egypt.

\subsection{The decline of presidential interest in youth issues} In 1999, the Ministry of Youth was reintroduced into the cabinet of Dr Atef Obeid, following an absence that had lasted for the entire Mubarak presidency. This was a good sign, for it suggested a renewed interest in the welfare of young people.
Another good sign was the speech President Mubarak made in the opening joint session of the People's Assembly and the Shura Council on 13 November 1999. In this speech, Mubarak attributed the creation of a Ministry of Youth to the growing interest in the "future of promising generations which must have everything they need to become part of the modern age in which technological achievement depends on the intellectual resources of the people' (Ministry of Youth 2003). This tone persisted in later speeches made by President Mubarak in 2000, 2002, 2003 and 2004, when he spoke at length about the importance of integrating the youth in decisionmaking and involving them in party activities. Public policy, the president said, must rid itself from 'bureaucratic regulations that stifle talent and undermine honourable ambition' (Mubarak 2002). According to the NDP programme for 2002, the president placed great hopes on 'the youths of Egypt who represent the largest proportion of the Egyptian people'.

The president is also cited as having formed a committee for youth inside the NDP Policies Secretariat. The committee composed of executives and experts interested in youth affairs is said to have made valuable studies. 
Any optimism that this rhetoric generated was short-lived. Soon, signs emerged of a declining presidential interest in youth affairs. The first sign was the decreased frequency of references to youth issues in presidential speeches. The word 'youth' and its derivatives were mentioned twice or less on average in the speeches the president made at the joint sessions of the People's Assembly and the Shura Council in the period 2005-10 and when mentioned, focused on old issues.

The second sign of reduced presidential interest in youth issues has to do with the rare appearances of the president in youth events in the past ten years. In 2002, he even stopped showing up for the annual meetings of university youths, which he had attended regularly since coming to power. He also failed to attend any session of the four national conferences for youths held between 2007 and 2010, although these were organised under his aegis, and he attended other events of equivalent importance, including the National Conference for Upgrading High School Education and the National Conference on Population. The only youth meeting Mubarak attended was with the graduates of the National Project for the Vocational Training of Youth, run by the Ministry of Military Production, on 25 October 2005. Likewise, Mubarak did not meet the NDP youths nor did he hold a dialogue with them during his entire presidency, aside from a meeting with several NDP youths who spoke to him about personal and career matters at the end of the 6 th NDP Annual Congress in September 2009.

The third sign is that the president hardly held any meetings with any of the youth ministers ${ }^{1}$ in the period 1999-2005, although the presidency told the youth ministers in question more than once to get prepared for such a meeting. Even the one meeting the president held to discuss youth policies on 8 October 2007 failed to produce tangible results. The meeting came up with guidelines, including instructions to ministers to build a youth centre in every village with a population of 5,000 or more; but none of these were implemented, no allocations were made, and no timetable was set. ${ }^{2}$

\section{The failure of the political leadership to draw} up a national policy for youth

The 'inner circle' of the government and party elite during the Mubarak years made little or no headway on youth issues, even with the personal interest of Gamal Mubarak, the president's son, in acquiring youth support for his political ambitions. Successive governments failed to adopt a public policy for youth or produce an authoritative government paper on youth to match, for example, the national policies on women and children. No action was taken to emulate youth policies in other Arab countries such as Jordan and Bahrain. This happened despite the fact that the Ministry of Youth and the Youth Committee of the NDP Policies Secretariat saw the need to issue a national policy for youth. They urged the formulation of a practical framework delineating the official policy on youth, spoke of enhancing coordination between various players in the field of youth, and mentioned that the ministries and competent departments involved should turn the stated goals and strategies into working plans and executive programmes.

The perception of youth problems by the NDP left much to be desired, for although the NDP leaders constantly boasted of the increased ratio of youths in the 18-40 age group in the party, which stood at 49.4 per cent of the total membership in October 2008, the party's interest in the youth was mostly for propaganda purposes. In other words, the party tried to overcome the ageing image of its leadership and parliament members and to appear with a youth face. This would seem to help in mobilising support for the party potential candidate in 2011 presidential elections.

In all general and annual conferences held by the party in the period 2002-10; with the exception of the 3rd General Congress of 2005, which coincided with presidential elections, the Youth Committee of the NDP Policies Secretariat made a habit of issuing a special policy paper. But none of the most credible policies that the committee proposed were implemented by competent government bodies.

The ruling party was aware of the need to coordinate with the government concerning the planning and implementation of youth policies, and so established a special working group led by NDP High Policy Secretary Gamal Mubarak, and included Dr Ali Al Dean Hillal Dessouki, member of the NDP Bureau and former youth minister; the Minister of High Education; the Minister of State for Scientific Research; the head of the National Youth council; the coordinator of student activities in Egyptian 
universities; the head of the Youth Committee in the NDP Policies Secretariat; a member of the National Youth Council; and the NDP youth secretary. This committee met only twice: in December 2010 and January 2011. Its memos spoke of the shortage of funding allocated by the government to youth activities and said that the available money was thinly spread among too many ministries and organisations (Hillal pers. comm.).

\subsection{The inadequacy of the legislative framework regulating the youth movement}

Under Mubarak, laws concerning the youth were neglected by legislators. Not one law related to the youth was passed during the entire Mubarak era. Law 77 for 1975, concerning organisations active in the field of youth and sports, of which some provisions were modified in May 1975, remained the only legislative framework organising action concerning youths in Egypt until 2011. Even this law, flawed as it was, was only partially implemented. For instance, Section 8 of the said law, concerning the creation of a general federation for youth organisations engaged in voluntary work, was never implemented. In July 2004, the Youth Minister pushed for an amended form of this federation, calling it 'The Union of Voluntary Work for Youth'. ${ }^{4}$ The union, which was supposed to coordinate among various organisations working in this field, never saw the light.

Most of the laws addressing youth affairs were passed without taking the views of the youth into account. Take for example the law on nongovernmental organisations (NGOs), No 84 for 2002, and its executive regulations, No 178 for 2002; the laws concerning the exercise of political rights, which did not allow people under the age of 30 to run for membership of legislative councils; and the regulations and administrative decisions related to the implementation of some laws such as the student bylaw No 265 for 1979 none of these were issued in consultation with the youth organisations: either because of the inactivity of youth organisations at the time; because of subsequent changes, as was the case with the law on NGOs or because the political environment was unfavourable, as was the case with the student regulations.

As the discrepancy between reality and the rhetoric persisted, both the government and the party continued to speak about their interest in energising the youth and embracing their ideas. Subsequently, the youth felt alienated and distrustful of the public policies. The youth were also skeptical of the reforms the government was pursuing in the political and economic spheres (Shoaeb 2004) Their rejection of official policies was often the result of the government's reluctance to address urgent problems. Among the disadvantaged youths, resentment of the wealthier and better educated classes who had access to better jobs was widespread.

\section{The policy failures in education, employment and political engagement}

Although government policies took considerable interest in youth issues, decision-makers failed to make budgetary allocations or introduce executive plans to address youth-related problems. There follows a review of the policies of higher education, employment, political engagement, and social integration in the last ten years of Mubarak's rule, as well as the reaction of the youth thereof.

\subsection{The education policy}

Under Mubarak, government officials often spoke of the need to restructure the entire system of education. The final year of high school, the evaluation methods, examinations, ennoblement in universities, training for the labour market, revision of technical education to make it compatible with the requirements of business, were all discussed. Officials also saw the need to address 11 important challenges facing the entire system, such as the need to provide adequate guarantees for equal opportunity, to enhance the quality of technical education, to change the culture and societal opinion of college graduates, to link the system of enrolment in higher education with students' aptitudes and the requirements of the labour market, and to sort out the question of funding, which is crucial to educational reform (Mubarak 2008).

The vision was there, so was the recognition of the importance of the issues at hand. But the policies often failed to come into action. Some faced real difficulties in implementation due to the low spending on education. As a ratio of the GDP, spending on education remained particularly low during the period 2004/05-2008/09. The ratio was 4.8 per cent in 2004/05; 4.2 per cent in 2005/06; 4.1 per cent in 2006/07; 3.5 per cent in 2007/08 and 3.3 per cent in 2008/09. In absolute terms, 
however, the expenditure rose steadily, reaching EGP36 billion in 2008/07.

The biggest item in the spending on education was wages. These made up 82 per cent of the total expenditure in pre-college education in 2006/07. The remaining needs of the educational process were clearly at a disadvantage. This prompted the head of the NDP Education Committee to ask for the allocations on education at 6-7 per cent of the state's budget for ten consecutive years. He also advocated increased reliance on the private sector in the financing and running of schools and universities, as well as the enhancement of remote teaching (Badrawi 2011).

The shortage of finance was particularly acute considering the growing number of students. The high number of students registered in college education and government and private institutions (2.4 million in universities, 130,076 in technical institutes during the year 2008/09) meant that a growing number of graduates were seeking jobs every year. The latter, as various field studies and conference papers indicated, voiced their dissatisfaction with the outcome of the educational system. Dissatisfaction with the quality of education was particularly acute in the applied-science colleges, as the lack of laboratories and equipment hindered scientific training. Consequently, graduates found themselves lacking the skills required by the labour market. Shortages of foreign language and computer skills were often cited in this regard. The ratio of underqualified graduates, according to some government studies, reached 27.3 per cent of the total (Egyptian Cabinet IDSC 2011). This led to problems in getting jobs and to a widespread feeling of frustration and disillusion among the youth (ICFS 2006).

Among the youth of the underprivileged classes, a growing feeling of alienation took root.

Enrolment in private universities - which numbered 18 by the end of 2010 - or even departments of foreign languages in some colleges, such as those of economy and political sciences, commerce and law, ${ }^{5}$ was out of reach for the poor, and no financial programmes to help top students of limited financial needs existed, except in few universities and for a limited number of students. The question of equal opportunity and social justice was a serious one, especially as some of these universities admitted affluent applicants with little more than a scant consideration for their academic aptitude.

The restrictions placed by the government and the security apparatus on the freedom of students to voice political views inside the universities were considerable. Restrictions were placed on membership in student unions and societies, and even on guest speakers from the opposition. The restrictions were such that the student bylaw for 1979, and its amendment by republican decree No 340 for 2007, made the approval of such activities subject to the consent of the security services, thus fuelling resentment among the youth of all political currents, with the notable exception of NDP members. As of 2006, the Muslim

Brotherhood youth began forming parallel student unions in some universities. These unions, known as 'The Free Student Unions', were met with more restrictions by the university administration and security services. Consequently, several students were expelled and others arrested. Frustration was widespread among underprivileged, out-of-town students of the political opposition, who were denied places in university dormitories. Students were not allowed places in dormitories unless they were vetted first by the security services (Saber 2007). In other words, students who were poor and from the opposition suffered from dual discrimination: once because of their limited means and again because of their political views.

\subsection{Employment policies}

According to official figures released by the Central Organisation for Public Mobilisation and Statistics in 2010, the rate of unemployment among the youth was 20.4 per cent in the 18-29 age group. The ratio was higher for males with college degrees than for holders of high school diplomas and holders of technical education diplomas, at 26.8 per cent, 19.3 per cent and 11.2 per cent, respectively. The ratio was particularly high among females with technical education diplomas, females with a college degree and females with high school diplomas, at 56.1 per cent, 55.1 per cent and 45.5 per cent, respectively. The ratios were even higher in the survey of young people conducted in 2009, which showed that nearly 58.5 per cent of youths in the above age group were unemployed; the ratio being 83 per cent for females and 27 per cent for males.

In general, unemployment was higher among the educated than among the less educated and 
among females than males, especially in the post-high school category. The ratio went down for both sexes after the age of 21 , with greater improvement among males. By age 29, males seem to be able to find some form of employment (Assaad 2010).

The problem of unemployment is associated with many factors, chiefly the population increase, the size of the workforce, and the inability of the labour market to provide jobs for all graduates, especially the less qualified. The privatisation policies which the regime started in the early 1990s made unemployment worse as a result of the laying off of excess labour (Dessouki and Mamdouh 2000). Since the introduction of economic reform policies in 1991, successive governments have failed to find the right 'technological option' for the country. As foreign and domestic companies were encouraged to bring in the latest technologies in production, the demand on labour dwindled.

In his electoral programme for 2005, President Mubarak promised to create 4.5 million jobs within six years. He also pledged to improve the educational process in the aforementioned manner and to stimulate demand in foreign markets for 'trained' Egyptian labours but these efforts brought no tangible results. Meanwhile, the number of young people entering the labour market for the first time kept going up, the quality of education went down, and the needs of the labour market remained incompatible with the skills provided by the educational system. There was also reluctance on the part of the youth (86.3 per cent of males and 74.9 of females) to venture into business. Most of the youth thought the state and the decision-makers were under obligation to provide them with work. Adding to this problem were the multiple impediments the youth faced when seeking loans from the Social Development Fund (SDF). The small- and medium-scale businesses, which the loans were intended to stimulate, were meant to provide 42 per cent of jobs in Egypt by 2020.

Since its foundation in 1991, the SDF provided loans for small and micro-businesses, totalling EGP10.86 billion. But the impact on the small and micro projects dedicated to the youth was meagre, partly because the law does not grant youths a preferential interest rate in the same manner it grants other disadvantaged groups, such as the inhabitants of informal areas, people most harmed by economic reform programmes, single mothers and people with special needs. In the case of the above groups, as well as of companies that specialised in food security and animal breeding projects, the interest rates were 1 per cent, 2 per cent and 3 per cent,

respectively. But for small projects for the youth, the rate was 7 per cent or more (Al Ahram 2009).

The second problem is that many youths have been unable to provide the collateral the SDF requires for lending. A third problem is that a major proportion of the youth failed to see the point in starting a business and lack basic business skills. A fourth problem is the common fear of defaulting, and the common notion that defaulters may face imprisonment. The SDF general secretary repeatedly denied that action leading to the imprisonment of defaulters had been taken. But a large number of youths felt that the state was 'trying to exploit them to obtain high interest on the loans it offers'. Officials in charge of the programme often felt that the youth lacked seriousness and were trying to 'con' them. Another problem was the difficulty of marketing the products produced in the new start-ups by young people, which was perhaps due to the competition posed by cheaper foreign products. Also, the state departments which are in charge of developing small projects seem to have lacked a comprehensive vision. Most of the time, they focused on industrial rather than agricultural projects, although there is much room for investment in land reclamation. In fact, the country could have used a bank that specialised in the finance of small projects, similar to the Grameen Bank in Bangladesh, which is sometimes called the 'Bank of the Poor'. Some studies have been made in this regard but none have been implemented (ICFS 2006). Aside from the SDF, there are other government departments which support the provision of loans for youths to start small projects. Some banks have also become involved. But none of these efforts have been successful, partly because of their lack of expertise in the field, their aversion to risk and their exaggerated requirements for guarantees. Remarkably, the electoral programme of President Mubarak for 2005 called on banks to form specialised branches for small loans and urges the creation of a network of institutions, including post offices, to handle such loans. According to the programme, the portfolio 
of credit related to small projects must increase, and the bank reserves linked to allocations of small loans must be brought down. The programme also urges the abrogating of excessive guarantees. It calls for providing technical support for the pre-production and post-production services. ${ }^{6}$ None of the above recommendations has gone into effect, and the problems facing the youth seeking credit for their small and micro projects remain considerable. On the upside, lending for medium-scale industries has been more successful.

The final years of the Mubarak era saw nepotism and cronyism taking hold of the job market. According to a survey of youths conducted in 2009, nearly 42 per cent of the young believed that having wasta (connections) was crucial for employment. The survey shows this feeling grows with age, from 38.8 per cent among those aged 15-17, to 46.6 per cent among those aged 25-29. The ratio is higher among low-income families than middle-income ones -46.6 per cent and 32.2 per cent, respectively. It is also higher among graduates of post-high school institutions, who feel marginalised by society.

A study about cultural modalities in Egypt confirmed this trend. A study on the values of probity, transparency, and corruption, which was conducted by the Ministry of State for

Administrative Development in October 2009, involved a survey of 2,000 people aged less than 35 years. It concluded that the youth were the most outspoken about the increase of nepotism in the period 2004-09. About 90.1 per cent in the above age group, compared with 88.7 per cent and 80.2 per cent, in older age groups, complained of nepotism. Nearly 90.7 per cent of the youth stated that they needed wasta to get anything done.

Nearly 83.6 per cent of those interviewed said that corruption was growing in Egypt and that the group most at a disadvantage, after the uneducated, was the youth, among whom 52.2 per cent said they were left out. The youth is also the second most mistreated people in society after the poor, a view held by 39.8 per cent of the interviewees (Zayed 2009).

Certain practices hampered equality in the job market. One is that some employers favour socially privileged candidates and the offspring of existing employees. The suicide case of Abdel Hamid Sheta, a graduate of the Faculty of
Economy and Political Science, illustrates this situation. Deemed 'socially unfit', Sheta was blocked from joining the diplomatic corps, and consequently took his own life. ${ }^{7}$ The sons of the policemen, military men and judges tend to get appointed in the same jobs as their parents, mostly because they have no trouble passing the 'appearance test'.

The failure of youths to find a suitable job (30 per cent males, 40 per cent females), is compounded by other problems. One is the difficulty of finding affordable housing. The government has launched several projects to give youths the chance to own housing units at subsidised rates. A total of 235,000 housing units were built during the period 2005-09, but the prices of these units exceeded the means of disadvantaged youths (Madbouly 2010).

As many young people tended to remain unemployed for long stretches of time, they were unable to get married. For women, the problem of finding a husband got worse, as the average age for marriage among men in 2009 reached 29 years, an age which is $3-4$ years higher than their view of the preferred age for marriage. And the average age for marriage among females was 24 years, which is $2-3$ years higher than the age they deemed optimum. The high cost of marriage was cited as a major reason for postponing marriage (the view was shared by 61 per cent of males and 59 per cent of females). The difficulty of finding an apartment was also mentioned (by 52 per cent of males and 46 per cent of females). Consequently, 38 per cent of youths had to live with their parents after marriage, and 34 per cent of young people ended up marrying close relatives as families tended to be more lenient about financial matters in such situations (Sieverding and Elbadaw 2011).

\section{The policies of political initiation and social integration}

What is meant here by political initiation is the transfer of political culture from one generation to another, which allows for this culture to experience the alteration associated with modernisation and changing circumstances. The aim of such initiation is to preserve the identity of society and its social and political stability. This is where Mubarak, his government and the NDP have failed. They were unable to inspire new generations and make them sympathetic with the regime. They have also failed 
to allow alternative political institutions to grow. This is due to the following factors.

First, the NDP and its government have failed to create youth organisations similar to those created by Presidents Gamal Abdel Nasser and al-Sadat, such as the Liberation Youth Battalions, the National Youth Federation and the Socialist Youths Organisation, which provided the main conduit for political initiation for youth during the period 1963-76. The most the NDP and its government managed to do was to create generic youth gatherings that cannot be properly described as youth organisations. One example is the Horus Family, the Supreme Council for Youth and Sports created in the universities, following the African Olympics, during 1991-6. Another is the Generation of the Future Society, chaired by Gamal Mubarak. In its early years, 1998-2002, the latter was used to boost Gamal's popularity and groom him for a political role in the NDP. Training courses were offered to members of that group at subsidised prices, helping them to acquire basic aptitude in foreign languages and computers, as well as some management skills.

During Mubarak's presidency, NDP leaders and government officials spoke of supporting 'all the youths of Egypt without discrimination' and 'regardless of their partisan affiliations'. The NDP called on the youth to participate in social service, environmental campaigns and the summer camps it organised regardless of their political affiliation. And competent government departments told the youth to take part in summer and winter camps, maintaining that these activities were open to all young people of the various political parties, who wished to apply.

Second, the NDP was unable to attract youths who believe in the party's principles and ideas. The NDP failed to create and train loyal political cadres for a number of reasons. One is the absence of a religious, ideological, political and economic doctrine to entice the youth to join it rather than sign up with other groups, such as the religiously based Muslim Brotherhood, the socialist and Marxist leftist parties, or even the liberal parties including the Wafd, whose legacy goes back to the pre-1952 era. Unlike the custom in some Arab parties, such as the Syrian Baath, the NDP and its government refrained from hiring the young members of the ruling party in the government apparatus. The only advantage the youth gained from joining the NDP was proximity to people with influence, which potentially boosted their social standing among their peers, especially if their personal ties with public figures and executive officials proved useful in resolving some problems among their immediate families and friends. Being part of a 'winning team' was the main motivation for young NDP members. Another was the subsidised services offered by the NDP, which were particularly attractive to disadvantaged young people eager to join in summer camps. Access to language and computer classes, and occasional help with college-level classes was also a factor (Mamdouh 2010). There was no clear plan to train and engage NDP youths in the last five years of Mubarak's rule. This is evident in the diminishing activities of the Training and Political Indoctrination Secretariat and the infrequency of training courses it offered, alone or in conjunction with other NDP secretariats, such as those of youth, information and organisation (NDP 2009).

Membership of the NDP, especially among the youth, was mainly motivated by political gains and the desire to have access to people with power and influence. The spectacular failure of the NDP to mobilise its young members during the events of 25 January-11 February 2011, prompted Policies Secretary Gamal Mubarak to chide Organisation Secretary Ahmad Ezz: after the fall of the regime, Gamal was quoted as asking Ezz 'Where are the Future Youths you kept boasting about, and where is the selfmotivated young rank and file?' (Al Ahram 2011).

Third, the government followed a traditional system for political and cultural initiation which focused mainly on filling youths' time with social and entertainment activities, with the latter dominating activities in the youth camps. The youth centres failed to engage the young in political training and indoctrination. For example, participation in the Youth and Vanguard Parliamentarians in the youth centres - which is the main programme for political initiation in the Youth National Centres - was remarkably low from January 2006 to January $2011 .^{8}$

This was coupled with a failure to put together a strategy to use the networks of youth centres. There were 4,435 centres across the country in 
October 2011, but they were not used as a political forum through which the youth could engage, regardless of their political and intellectual preferences. No political activities were encouraged in youth centres, partly because NDP members of the People's Assembly, of the Shura Council, and of local councils controlled most of the boards running these centres, and partly because the security services blocked members of the opposition from getting elected to these boards. Moreover, the Supreme Council for Youths and Sports (SCYS) banned any political activity in these centres during the general elections, a decision meant to deprive the candidates of the opposition and the Muslim Brotherhood from using these centres. The ban was not fully enforced in the case of NDP candidates, who were allowed on occasion to use the centres in campaign-related activities.

Another failing of the system of political initiation has to do with the exclusion of the youth of various parties and youth movements from the national conferences organised by both the Ministry of Youths and the SCYS.

Participation in the said conferences was limited to individuals nominated by various universities and governorates, i.e. mostly NDP members. No effort was made to include the young 'outsiders' who were active on social networks, such as Facebook and Twitter. In the SGYS organisational structure, no job existed for communicating with the youth using social networks and no one seemed to be interested in inviting the latter to various events.

Fourth, ministries and various government departments failed to coordinate their programmes for political initiation and democracy training. This was partly due to the lack of a central database listing the names of potential participants. Also, the definition of 'youth' differed from one department to another. This resulted in the duplication of the services provided to the youth, and greatly limited the number of beneficiaries from various state programmes, who were a tiny fraction of Egypt's young population. Government departments also failed to play a key role in enlightening the youth. For instance, during 2001/02, the country's state-run television decreased the air time for political programmes targeting the youth while boosting entertainment to 30.5 per cent of the total transmission hours (Kamal
2004). The total air time for youth programmes in 2009/10, in all state-run television stations, was 2,671 hours. Of these, 1,460 hours, or 54.6 per cent of the total, were dedicated to the Family and Child Channel, a service known for its focus on social entertainment (Ministry of Information 2011). The lack of effective youth policies and the absence of coordination between the NDP and its government in areas related to the political initiation and training of the youth led to two things.

First, the youth became averse to participating in political parties and social society organisations. Membership of political parties amounted to 2.2 per cent of the social activities of young people; for the 18-29 age group it is 0.12 per cent. According to available figures, the participation of youths in volunteer activities averaged 3 per cent (4.5 per cent among males and 1.5 per cent among females) (Barsoum et al. 2010). Among Egypt's 35,000 NGOs in Egypt, only a few are dedicated to youth-related activities, and even those have a relatively low membership. Reliable data on the effectiveness of youth organisations is lacking. According to a World Bank study released in May 2007, only 122 youth NGOs existed in Egypt (Al Rouby et al. 2007). Another study puts the figure at 310 youth NGOs, including eight central societies that have branches in the governorates (Kandeel 2007).

Second, the youth turned to other groups for political learning and training. During 1981-2004 these groups included the Muslim Brotherhood and the Gamaah Islamiya. Since 2004, new social movements began attracting the youth, including Kifaya (Enough) and Shayfeencom ('We are Watching You'). Internet-based protest movements such as the student-run 'My Right League' (rabitat haqqi) became particularly active in late 2007, speaking out, for instance, against the increase of tuition fees in the colleges of medicine and engineering in Ein Shams University. The emergence of the April 6th group in 2008 and the 'We are all Khaled Said' group on Facebook in 2010 proved to be groundbreaking. These groups offered new channels for youth activities because of their clear goals, proper understanding of youth problems, and willingness to try new methods of action, all of which contrasted with the government's outmoded ways. 


\section{Conclusion}

Mubarak's regime has failed to deal with the 'revolutionary' youths and could not recognise the new changes that globalisation have brought about. Confining itself to a loose political discourse about empowering the youth and about giving them the chance for upward mobility, the regime failed to offer any tangible work, either materially or in cyberspace. It has failed to bank on the sense of hope that evolved since 2005, when the country's first competitive presidential elections led to greater freedom of expression, as was seen in television chat shows, the independent press and the social networks. This sense of hope could have been used to 'energise the youths' and 'revitalise the regime', but instead it was wasted.

The above-mentioned issues were not, however, the only ones that accelerated the uprising of the youth and ultimately brought down the collapse of the regime. Other issues were also involved, such as the regime's habit of going back and forth between democracy and dictatorship. The

\section{Notes}

1 It is worth mentioning that most of the chairmen of the Higher Council for Youth and Sport and Ministers of Youth had occupied prominent positions in the NDP.

2 Remarks of Ministry of Youth and National Council of Youth are drawn from the researcher's own professional work experience in these bodies.

3 Interview with Dr Ali Al Dean Hillal Dessouki, member of the NDP Bureau and former Youth Minister, on 10 August 2011.

4 Annual Conference of Youth Researchers (2004) Cairo: Center for the Study of Developing Countries.

\section{References}

Al Ahram (2011) 19 April

Al Ahram (2009) 19 October

Al Rouby, H.; Samra, M.; Helmy, G. and Refay, M. (2007) Mapping of Organizations Working with and for Youth in Egypt, World Bank: CapacityBuilding and Knowledge-Sharing Partnership Program for Youth Organizations

Assaad, R. (2010) 'Human Development and Labor Markets', in H. Heba (ed.), Egypt Human Development Report Youth in Egypt: Building our Future, Cairo: United Nations Development Programme and Institute of National Planning: 147-62 regime's hybrid manners and inconsistent approach allowed corruption and nepotism to fester. As a result, the youth felt that their future depended to a large extent on what kind of connections they had with the government and NDP officials. Considering that the legislative elections were crudely rigged and that the state institutions were not functioning efficiently, the youth felt that the regime's days were numbered.

The fate of the Egyptian youth will depend in the future on many factors. Prominent among which, is the degree of political commitment of the new elected president and parliament towards youths, as will be shown in the budget allocated to their needs and ambitions and the issuing of a nationally binding youth policy which will offer a comprehensive framework to deal with youth in Egypt. Without this commitment, the end of the Mubarak regime will be only a historical moment and a step forward towards a new kind of youth marginalisation.

5 There are 18 private universities in Egypt according to the statistics of the Supreme Council for Universities.

6 Mubarak's Electoral Program: President Program in Points, Cairo, August 2005.

7 There is much more news on the relation between this incident and the eruption of the January 25th uprising. For instance, see: Abd Al Hameed Sheta, 'Burned in Order We Win', Al Arabi Al Nassari newspaper, 15 February 2011.

8 Detailed information can be found within the political empowerment sections of the annual reports issued by the National Council of Youth during the period 2006-10.

Badrawi, H. (2011) Education. Opportunity for Rescue, Cairo: Egyptian Lebanese Publishing House

Barsoum, G.; Ramadan, M. and el Kogali, S. (2010) 'Youth Life Transitions: Opportunities, Capabilities and Risks', in H. Heba (ed.), Egypt Human Development Report Youth in Egypt: Building our Future, Cairo: United Nations Development Programme and Institute of National Planning: 193-204

CAPMAS (Central Agency for Public Mobilization and Statistics) (2011) Cairo, 14 August

Dessouki, Ali Al Dean H. and Mamdouh, I. (2000) 'Youth Policies: Aspirations and Challenges', in S. Salwa (ed.), Youth Policies: 
Aspirations and Challenges, Cairo: Public Administration Research and Consultation Center: 1-49

Egyptian Cabinet IDSC (Information and Decision Support Center) (2011) Issues of Egyptians Youths and Youngsters: Education, Employment and Immigration, Information Reports Series 51, March

ICFS (International Center for Future and Strategic Studies) (2006) Youths and the Culture of Entrepreneurship, Youth Culture Program, Cairo, Egypt, 25 January

Kamal, A. (2004) 'Role of Media in Formulating Youths Culture', in N. Al Fawal (ed.), Youth Programmes in the Egyptian Television: A Study of Audience, Cairo: National Center for Social and Criminological Research

Kandeel, A. (2007) Youth Organizations in Egypt, Cairo: United Nation Fund for Population in collaboration with Arab Network for Civil Society Organizations

Madbouly, M. (2010) 'Housing and Transportation: A Youth Perspective', in H. Heba (ed.), Egypt Human Development Report Youth in Egypt: Building our Future, Cairo: United Nations Development Programme and Institute of National Planning: 193-204

Mamdouh, M. (2010) 'Political Matters of Your Concern', Al Tabbin Youth Magazine, Halwan: Youth Secretariat of Al Tabbin District Ministry of Information (2011) Study on Air Time Youth Programmes during the Financial Year 2009/2010, Internal Document
Ministry of Youth (2003) Annual Report 2002, Cairo: Ministry of Youth

Mubarak (2008) Speech at National Conference for Developing the Secondary Education and Acceptance Policies of Higher Education, Cairo, 12 May

Mubarak (2002) Speech, Cairo, 16 November NDP (2009) Annual Report, Cairo: National Democratic Party: 43-6

Saber, K. (2007) University Independence, Cairo: Cairo Institute for Human Rights

Shoaeb, M. (2004) 'Attitudes of Youth Perception and their Position towards the Speech of Reform and Political Change of Different Political Forces in Egypt', in Amr Hamzawi (ed.), Between Slogan and Reality: Speeches and Reform Programs in a Changing World, Fifth Annual Conference of Youth Researchers, Cairo: Center for the Study of Developing Countries

Sieverding, M. and Elbadaw, A. (2011) Marriage and Family Formation in Population Council West Asia and North Africa Office, Survey of Young People in Egypt 2009, Final Report, Cairo: Population Council West Asia and North Africa Office

Zayed, A. (2009) Cultural Determinants of Egyptian Behaviors and Choices: A Study of Integrity, Transparency and Corruption, Cairo: Ministry of Administrative Development 